\title{
Trophic position of bottom-feeding fish in the Upper Paraná River floodplain
}

\author{
Lopes, CA. ${ }^{\mathrm{a} *}$, Benedito, E. ${ }^{\mathrm{a}, \mathrm{b}}$ and Martinelli, LA. ${ }^{\mathrm{c}}$ \\ aPrograma de Pós-graduação em Ecologia de Ambientes Aquáticos Continentais - PEA, \\ Universidade Estadual de Maringá - UEM, \\ Av. Colombo, 5790, Jardim Universitário, CEP 87020-900, Maringá, PR, Brazil \\ ${ }^{\text {b}}$ Departamento de Biologia - DBI, Núcleo de Pesquisas em Limnologia, Ictiologia e Aqüicultura - Nupelia, \\ Universidade Estadual de Maringá - UEM, \\ Av. Colombo, 5790, Jardim Universitário, CEP 87020-900, Maringá, PR, Brazil \\ ${ }^{\mathrm{c}}$ Centro de Energia Nuclear na Agricultura - CENA, \\ Universidade de São Paulo - USP, \\ Av. Centenário, 303, CEP 13416-000, CP 96, Piracicaba, SP, Brazil \\ *e-mal: lopes-celia@hotmail.com \\ Received: November 10, 2008 - Accepted March 4, 2009 - Distributed June 10, 2009
}

(With 3 figures)

\begin{abstract}
The $\delta^{15} \mathrm{~N}$ composition of bottom-feeding fish (iliophagous = Apareiodon affinis, Cyphocharax nagelii, Prochilodus lineatus, Steindachnerina brevipinna and S. insculpta; detritivorous = Loricariichthys platymetopon and Liposarcus anisitsi benthophagous = Satanoperca pappaterra and Hoplosternum littorale ) and their primary food sources were investigated in the upper Paraná River floodplain during rainy seasons in different environments (lotic and lentic). Two hypotheses were tested: i) that the trophic position and isotopic values of the investigated organisms (fish and food resources) vary spatially; and ii) that trophic position and isotopic compositions differ among iliophagous, detritivorous and benthophagous fish. $\mathrm{C}_{4}$ macrophytes, periphyton and phytoplankton were isotopically different in sites analyzed. Significant isotopic differences occurred in the species of each trophic category. Spatial differences were observed in the isotopic composition of P. lineatus and L. platymetopon, whose values were more enriched in the Paraná River and Pau Véio Lake. Significant spatial differences in trophic position were observed for L. platymetopon and H. littorale, which presented the highest values in the Paraná and Baía rivers, respectively. Trophic positions were significantly different among the species that composed each trophic category. These findings demonstrate that in energy-flow studies in detrital food chains generalizations concerning the grouping of fish into trophic categories and/or habitats should only be carried out after careful investigations of the local/specific trophic dynamics of the organisms.
\end{abstract}

Keywords: bottom-feeding fish, trophic position, nitrogen stable isotope, Upper Paraná River floodplain.

\section{Posição trófica de peixes exploradores de fundo na planície de inundação do Alto Rio Paraná}

\section{Resumo}

A composição de $\delta^{15} \mathrm{~N}$ de peixes exploradores de fundo (iliófagos = Apareiodon affinis, Cyphocharax nagelii, Prochilodus lineatus, Steindachnerina brevipinna e S. insculpta; detritívoros = Loricariichthys platymetopon e Liposarcus anisitsi; e bentófagos = Satanoperca pappaterra e Hoplosternum littorale) e suas fontes alimentares foram investigadas na planície de inundação do alto rio Paraná durante a estação de chuvas em ambientes lóticos e lênticos. Duas hipóteses foram testadas: i) que a posição trófica e os valores isotópicos dos organismos investigados (peixes e fontes alimentares) variam espacialmente; e ii) que a posição trófica e a composição isotópica diferem entre os peixes iliófagos, detritívoros e bentófagos. Macrofitas $\mathrm{C}_{4}$, perifíton e fitoplâncton foram isotopicamente diferentes entre os locais analisados. Diferenças isotópicas ocorreram entre as espécies de cada categoria trófica. Diferenças espaciais foram observadas na composição isotópica de P. lineatus e L. platymetopon, as quais tiveram valores mais enriquecidos no rio Paraná e ressaco do Pau Véio. Diferenças espaciais significativas nas posições tróficas foram verificadas para L. platymetopon e H. littorale, as quais apresentaram os maiores valores nos rios Paraná e Baía, respectivamente. As posições tróficas foram significativamente diferentes entre as espécies que compuseram cada categoria trófica. Estes resultados demonstram que em estudos de fluxo de energia em cadeias alimentares detritais generalizações a respeito 
do agrupamento de peixes em categorias tróficas e/ ou habitats devem ser conduzidos somente após investigações criteriosas da dinâmica trófica local/ específica dos organismos.

Palavras-chave: peixes exploradores de fundo, posição trófica, isótopos estáveis de nitrogênio, planície de inundação do Alto Rio Paraná.

\section{Introduction}

Bottom-feeding fish have an important role in the ecology of the ecosystems in which they live, as they process the pre-mineralization phase of organic material present in the mud, making it easier to decompose for microorganisms (Fugi, 1993), thereby accelerating the nutrient cycle (Gneri and Angelescu, 1951; Flecker, 1996). Furthermore, these organisms create indispensable links in the food chain, as they make the resources contained in the sediment available to pscivorous species. They have a high biomass in Neotropical rivers (Bowen, 1983; Lowe-McConnell, 1987; Hahn et al., 1997), and represent an important fishing resource for people who live by the river.

Based on an analysis of predominant food items in the contents stomach, Hahn et al. (1998) classified the bottom-feeding fish of the upper Paraná River floodplain into iliophagous (Apareiodon affinis, Cyphocharax nagelii, Prochilodus lineatus, Steindachnerina insculpta and $S$. brevipina), detritivorous (Loricariichthys platymetopon and Liposarcus anisitsi) and benthophagous (Hoplosternum littorale and Satanoperca pappaterra) trophic categories. However, conclusions concerning trophic relations based on stable nitrogen isotopes $\left(\delta^{15} \mathrm{~N}\right)$ show greater reliability than those of the usual techniques of studying diet (i.e. observation of food selection and/ or analysis of stomach contents) due to the fact that the tissues of the consumers reliably reflect the isotopic signatures of their consumed and assimilated food sources (Vander-Zanden and Rasmussen, 1996; Gu et al., 1997; Yi et al., 2006).

In the upper Paraná River floodplain, stomach content analyses have demonstrated that the ichthyofauna exploit food resources according to their habitats, commonly showing spatial variations (Lolis and Andrian, 1996; Hahn et al., 1997). $\delta^{15} \mathrm{~N}$ investigations carried out in the same area, have demonstrated variations in the trophic positions of P. lineatus, a bottom-feeding species, that are also interrelated with the various environments (Lopes et al., 2007). However, this species, which is regarded as a consumer, principally of mud (constituted for the most part by algae) (Fugi et al., 1996; Hahn et al., 1998; Luz et al., 2001), has reached the third trophic level in the Paraná River, which suggests that in addition to algae, it has also been exploiting and assimilating food sources enriched in protein and $\delta^{15} \mathrm{~N}$ (Lopes, 2007).

The elucidation and understanding of the trophic position of bottom-feeding fish, based on $\delta^{15} \mathrm{~N}$ composition, offer complementary information which help to explain the course of the detritus in the food chain of aquatic environments, as well as to trace the trophic relations involved in the strategy and ecological role of the species. Such information is fundamental for carrying out effective management and conservation tasks, which aim at maintaining fish populations at sustainable exploitation levels in the only dam-free section of the Paraná River in Brazilian territory.

Therefore, the objective of the present study was to investigate the $\delta^{15} \mathrm{~N}$ composition of bottom-feeding fish (iliophagous = Apareiodon affinis, Cyphocharax nagelii, Prochilodus lineatus, Steindachnerina brevipinna and S. insculpta; detritivorous = Loricariichthys platymetopon and Liposarcus anisitsi; and benthophagous = Satanoperca pappaterra and Hoplosternum littorale) and their potential primary food sources in the upper Paraná River floodplain during rainy seasons, testing the hypotheses that: i) the trophic position of the fish and the isotopic values of the organisms investigated (fish and food sources) vary spatially, and ii) trophic position and isotopic compositions differ among iliophagous, detritivorous and benthophagous fish.

\section{Material and Methods}

The biological material was collected during rainy seasons (February to March) from 1999 to 2004 in the Upper Paraná River floodplain $\left(22^{\circ} 40^{\prime}-22^{\circ} 50^{\prime} \mathrm{S}\right.$ and $53^{\circ} 10^{\prime}-53^{\circ} 40^{\prime} \mathrm{W}$ ) (Figure 1). The rainy season is the time when the entry of allochthonous material, originating from an adjacent marshy area, into the food chain energy flow in the floodplain is at its highest (Hamilton and Lewis-Jr., 1992). Within this ecosystem, the Paraná, Baía and Ivinheima rivers and the Pau Véio Lake, Maria Luiza, Finado Raimundo, Fechada and Ventura lakes were sampled. The last two lakes do not have a direct connection with the river and remain isolated throughout the year.

Three to five samples of the primary food sources of the fish were collected at each sampling site, consisting of the most common riparian vegetation, aquatic macrophytes $\left(\mathrm{C}_{3}\right.$ and $\left.\mathrm{C}_{4}\right)$, periphyton and phytoplankton. Each sample of riparian vegetation and aquatic macrophyte consisted of five leaves from different specimens of the same species. The species of vascular plants sampled were the most common ones at each sampling site (Campos and Souza, 1997). Periphyton was obtained by scraping the petioles of aquatic plants and retaining them in previously (calcinations) fiberglass filters (GFC-Whatman). Isotopic values for phytoplankton 


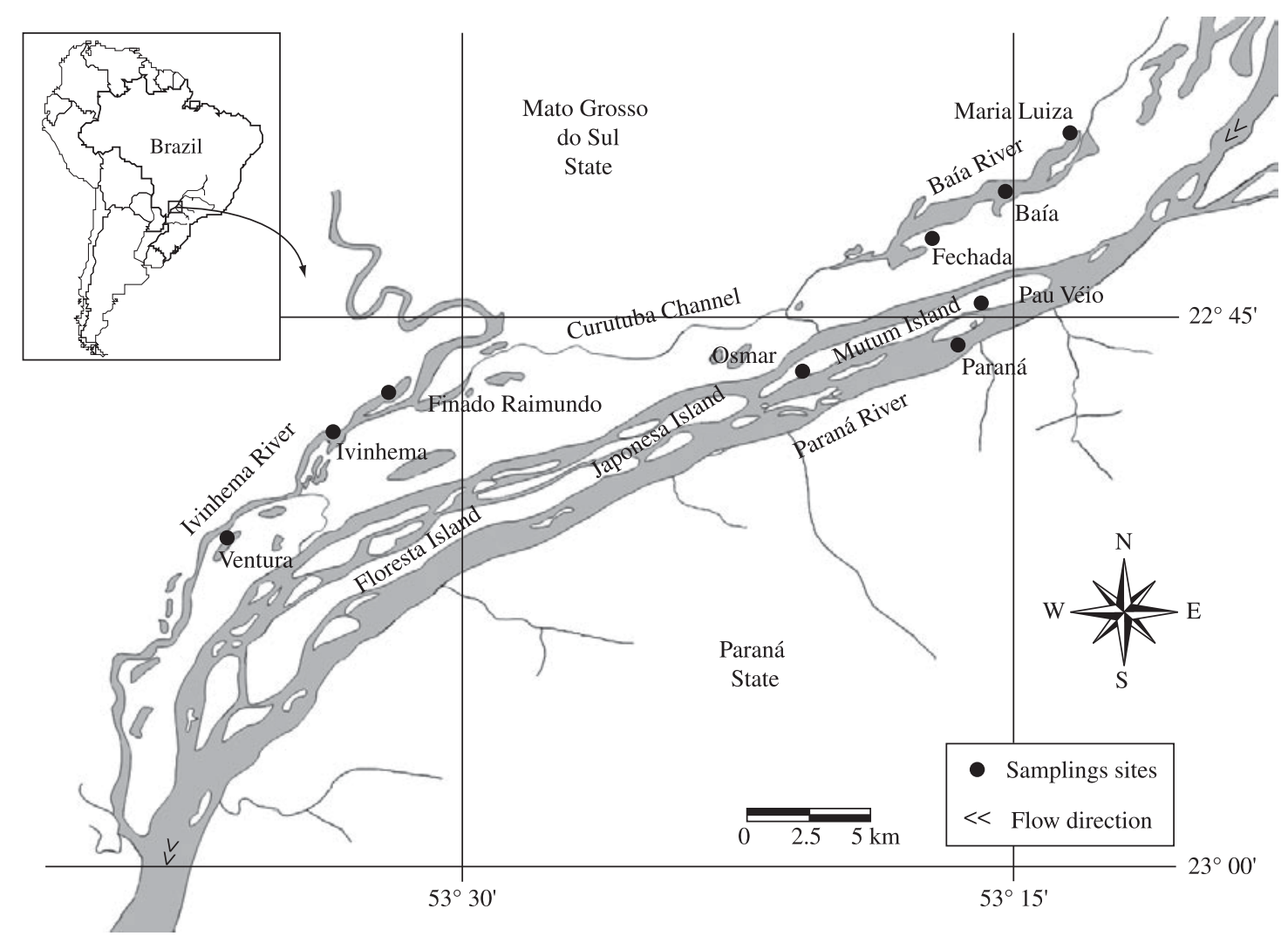

Figure 1. Map of the study area with sampling sites indicated.

were determined from filter zooplankton, considering the fractionation of $2.3 \%$ per trophic level (adapted from McCutchan-Jr. et al., 2003). Zooplankton samples (Cladocera and Calanoid copepod filter-feeders) were collected using a zooplankton net $(53 \mu \mathrm{m})$ and vacuum brush (through the filtering of water needed to form a sample). The samples were then rinsed in $1 \mathrm{~N} \mathrm{HCl}$ solution for the removal of carbonates.

Using either trap nets of different mesh sizes or dragnets at each sampling site, four to 15 adult specimens of the following species were captured: Apareiodon affinis (Steindachner 1879), Cyphocharax nagelii (Steindachner 1881), Prochilodus lineatus (Valenciennes 1836), Steindachnerina brevipinna (Eigenmann and Eigenmann 1889), S. insculpta (Fernández-Yépez 1948), Loricariichthys platymetopon Isbrücker and Nijssen 1979, Liposarcus anisitsi (Eigenmann and Kennedy 1903), Satanoperca pappaterra (Heckel 1840) and Hoplosternum littorale (Hancock 1828) (Buckup et al., 2007). These species have shown the greatest abundance in previous studies carried out at the sampling sites (FUEM/CIAMB-PADCT, 1993; Júlio-Jr. et al., 2000). Standard length $(\mathrm{cm})$ was measured and a muscle sample (approximately $2 \mathrm{~cm}^{2}$ ) was removed, close to the base of the first dorsal fin insertion, for each specimen.

All the samples, after being identified, were dried in ovens at $60{ }^{\circ} \mathrm{C}$ for 72 hours. They were then ground until a fine and homogeneous powder was obtained. Samples of approximately $3 \mathrm{mg}$ were sent to the Isotopic Ecology Laboratory of the Nuclear Energy in Agriculture Center (Centro de Energia Nuclear na Agricultura - CENA) for the determination of their isotopic ratio in a mass spectrometer, according to the equation:

$\delta^{15} \mathrm{~N}=\left[\left(\mathrm{R}_{\text {sample }} / \mathrm{R}_{\text {standard }}\right)-1\right] \times 103$

where: $R={ }^{14} \mathrm{~N}:{ }^{15} \mathrm{~N}$

The values of the isotopic ratios were expressed using the notation delta $(\delta)$ and parts per thousand $(\% o$ ), relative to atmospheric nitrogen.

The spatial isotopic differences of the organisms investigated and the trophic positions of the fish, as well as the variability among the trophic positions and isotopic compositions of the species of iliophagous, detritivorous and benthophagous fish, were investigated through Null Model Analyses of Variance, using the software ECOSIM 7.0 (Gotelli and Entsminger, 2003).

The estimation of trophic position was adapted from that proposed by Vander-Zanden et al. (1997):

$\mathrm{Pt}=\left(\delta^{15} \mathrm{~N}\right.$ fish $-\delta^{15} \mathrm{~N}_{\text {mean }}$ producer $) / \Delta+1$

where:

$\delta^{15} \mathrm{~N}$ fish $=$ the nitrogen isotopic value of the fish; 
$\delta^{15} \mathrm{~N}_{\text {mean }}$ producer $=$ mean nitrogen isotopic value of the primary producers;

$\Delta=$ the fraction of $2.3 \%$ (adapted from McCutchan-Jr. et al., 2003); and

$1=$ one trophic level above the primary producers.

The graphic analyses were carried out using the software STATISTICA 6.0 .

\section{Results}

\subsection{Composition and spatial isotopic variability of primary sources}

The $\delta^{15} \mathrm{~N}$ values of the primary producers varied from -2.0 to $13.6 \%$ (Figure 2 ). Significant spatial variability was observed for the $\mathrm{C}_{4}$ macrophytes ( $\mathrm{IO}=6.14$; $\mathrm{p}<0.05)$, periphyton ( $\mathrm{IO}=3.96 ; \mathrm{p}<0.05)$ and phytoplankton $(\mathrm{IO}=5.05 ; \mathrm{p}<0.05)$. The most $\delta^{15} \mathrm{~N}$-enriched mean values for $\mathrm{C}_{4}$ macrophytes and phytoplankton were found in the Pau Véio Lake. Periphyton had the most enriched mean values in Fechada Lake. The $\mathrm{C}_{3}$ plants did not show a significant spatial difference in the values.

\subsection{Composition and spatial isotopic variability of fish}

The isotopic composition of the species of fish varied from 3.5 to $14.4 \%$ ( $\mathrm{IO}=29.06 ; \mathrm{p}<0.05$ ) (Figure 3$)$. The greatest and smallest mean values were found for $S$. pappaterra $(13.4 \pm 0.5 \%$ ) and $H$. littorale $(8.1 \pm 0.3 \%$ ) , respectively. Significant spatial vari- ability was observed in the isotopic composition of P. lineatus $(\mathrm{IO}=9.67 ; \mathrm{p}<0.05)$ and L. platymetopon $(\mathrm{IO}=13.38 ; \mathrm{p}<0.05)$ (Figure $3 \mathrm{a}$ and $\mathrm{b})$. Both species had the most $\delta^{15} \mathrm{~N}$-enriched mean values in the Pau Véio Lake $(P$. lineatus $=11.9 \pm 0.7 \%$ and L. platymetopon $=11.5 \pm 2.3 \%$ ) and Paraná River $(P$. lineatus $=10.7 \pm 2.2 \%$ and $L$. platymetopon $=$ $12.9 \pm 0.9 \%$ ).

Significant isotopic differences were found among the species of fish that composed each trophic category. Among the iliophagous fish $(\mathrm{IO}=37.17$; $\mathrm{p}<0.05)$, the most enriched mean value in all sampling sites was found for A. affinis $(13.2 \pm 0.6 \%$ o $)$ and the poorest for P. lineatus $(8.4 \pm 2.1 \%$ ) . For the detritivorous fish, the mean isotopic composition of L. platymetopon $(8.9 \pm 2.2 \%$ o was higher than that of L. anisitsi $(7.2 \pm 1.6 \%$ ) in the majority of locations ( $\mathrm{IO}=12.37 ; \mathrm{p}<0.05$ ) (Figure $3 \mathrm{~b}$ ). For the benthophagous fish, the highest mean isotopic composition was found for S. pappaterra $(13.4 \pm 0.5 \%$ ) $(\mathrm{IO}=354.70 ; \mathrm{p}<0.05)($ Figure $3 \mathrm{c})$.

\subsection{Trophic position of bottom-feeding fish}

The mean trophic positions varied from 1.8 for L. anisitsi to 4.4 for $S$. pappaterra (Table 1). Significant spatial differences were recorded for $L$. platymetopon $(\mathrm{IO}=3.60 ; \mathrm{p}<0.05)$ and $H$. littorale $(\mathrm{IO}=15.29$; $\mathrm{p}<0.05)$. The highest trophic positions were found
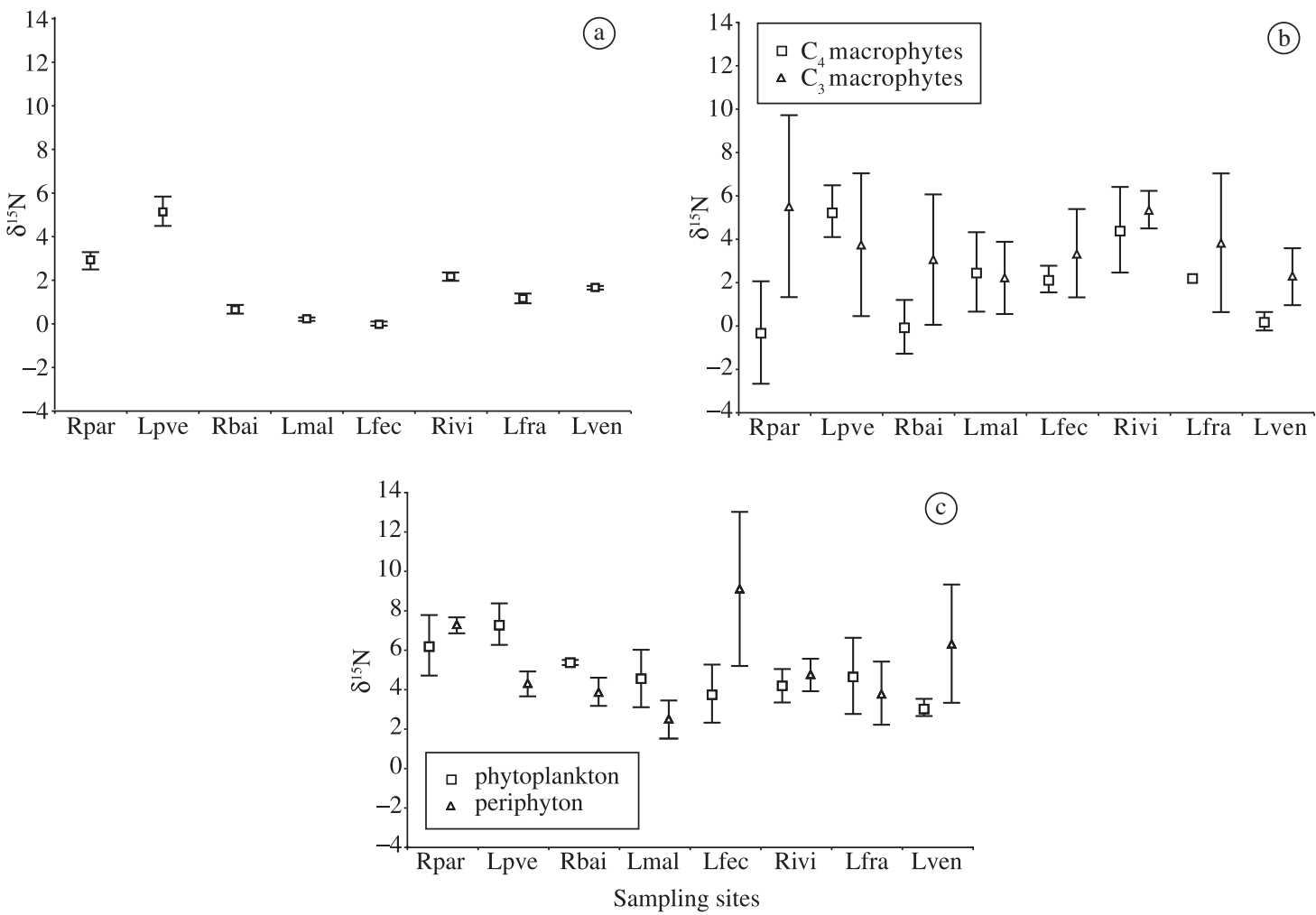

Figure 2. $\delta^{15} \mathrm{~N}$ mean values and standard deviation of the a) riparian vegetation, b) aquatic macrophytes, c) algae, for each sampling site: Rpar $=$ Paraná River, Lpve $=$ Pau Veio Lake, Rbai $=$ Baía River, Lmal $=$ Maria Luiza Lake, Lfec $=$ Fechada Lake, Rivi $=$ Ivinheima River, Lfra $=$ Finado Raimundo Lake and Lven $=$ Ventura Lake 

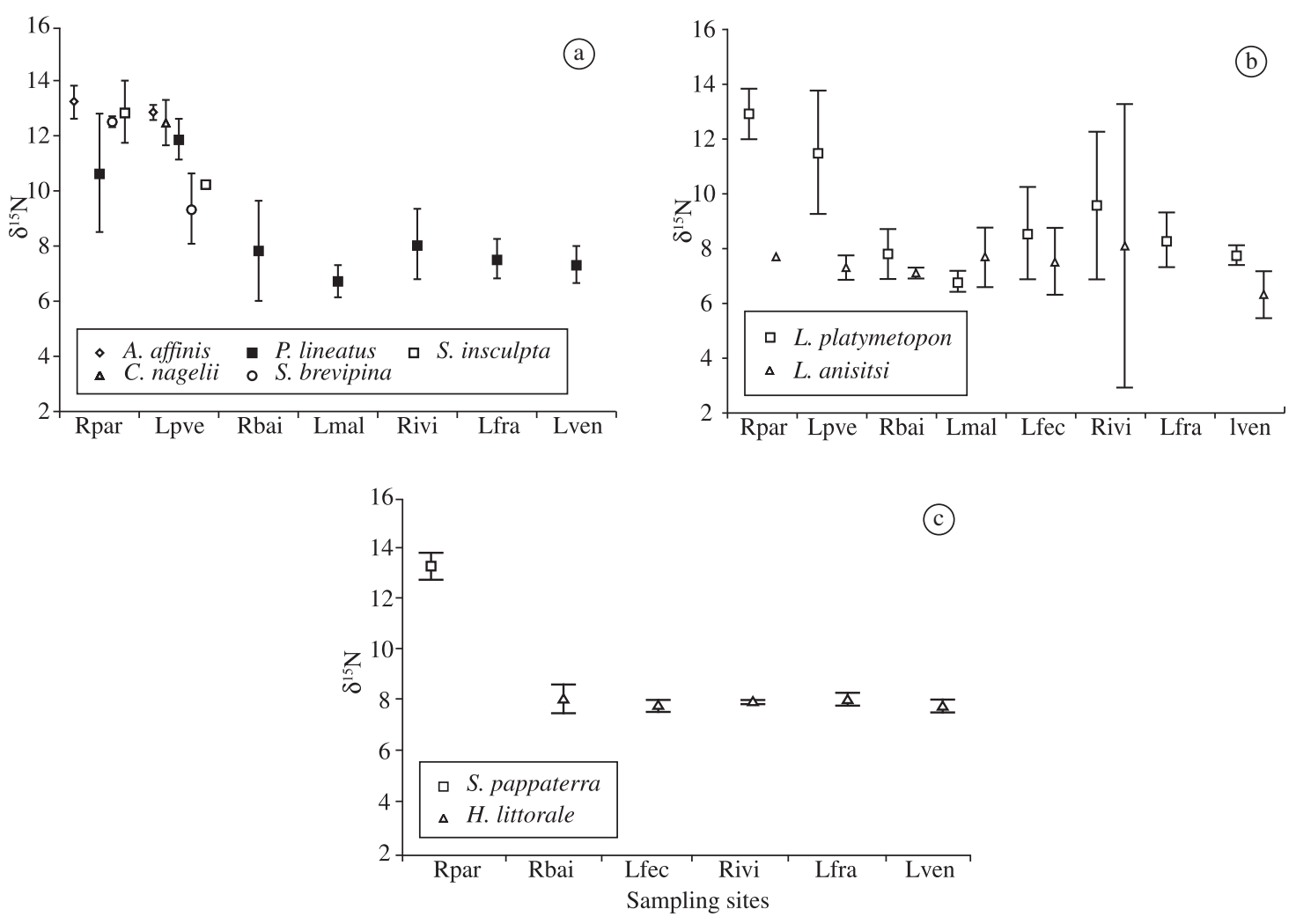

Figure 3. $\delta^{15} \mathrm{~N}$ mean values and standard deviation of the a) each iliophagous, b) detritivorous and c) benthophagous fish specie for each sampling site: Rpar = Paraná River, Lpve $=$ Pau Veio Lake, Rbai = Baía River, Lmal = Maria Luiza Lake, Lfec $=$ Fechada Lake, Rivi $=$ Ivinheima River, Lfra $=$ Finado Raimundo Lake and Lven $=$ Ventura Lake

Table 1. Mean trophic position of bottom-feeding fish for each sampling site: Rpar = Paraná River, Lpve = Pau Véio Lake, Rbai $=$ Baía River, Lmal $=$ Maria Luiza Lake, Lfec $=$ Fechada Lake, Rivi $=$ Ivinheima River, Lfra $=$ Finado Raimundo Lake and Lven $=$ Ventura Lake.

\begin{tabular}{|c|c|c|c|c|c|c|c|c|}
\hline Specie/sites & Rpar & Lpve & Rbai & Lmal & Lfec & Rivi & Lfra & Lven \\
\hline \multicolumn{9}{|l|}{ Iliophagous } \\
\hline A. affinis & 4.3 & 4.2 & - & - & - & - & - & - \\
\hline C. nagelii & - & 4.0 & - & - & - & - & - & - \\
\hline P. lineatus & 3.2 & 3.8 & 3.1 & 2.6 & - & 2.4 & 2.6 & 3.0 \\
\hline S. brevipinna & 4.1 & 2.7 & - & - & - & - & - & - \\
\hline S. insculpta & 3.1 & 4.2 & - & - & - & - & - & - \\
\hline \multicolumn{9}{|l|}{ Detritivorous } \\
\hline L. platymetopon & 4.2 & 3.6 & 3.0 & 2.6 & 3.1 & 3.0 & 2.9 & 3.2 \\
\hline L. anisitsi & 1.9 & 1.8 & 2.7 & 2.9 & 2.6 & 2.4 & - & 2.6 \\
\hline \multicolumn{9}{|l|}{ Benthophagous } \\
\hline H. littorale & - & - & 3.2 & - & 2.8 & 2.3 & 2.8 & 3.2 \\
\hline S. pappaterra & 4.4 & - & - & - & - & - & - & - \\
\hline
\end{tabular}

in the Paraná River $(4.2 \pm 0.4 \%$ ) and in the Pau Véio Lake $(3.6 \pm 0.9 \%$ ) for L. platymetopon, and in the Baía River $(3.2 \pm 0.3 \%$ ) and Ventura Lake $(3.2 \pm 0.1 \%$ o for H. littorale.
Significant variability in trophic positions was encountered among the species of each trophic category. Apareiodon affinis $(4.3 \pm 0.2 \%$ ), L. platymetopon $(3.2 \pm$ $0.7 \%$ ) and $S$. pappaterra $(4.4 \pm 0.2 \%$ o $)$ had the highest 
positions among the iliophagous ( $\mathrm{IO}=24.27$; $<<0.05$ ), detritivorous ( $\mathrm{IO}=15.90 ; \mathrm{p}<0.05)$ and benthophagous $(\mathrm{IO}=39.72 ; \mathrm{p}<0.05)$ fish, respectively

\section{Discussion}

The variability of $15.6 \%$ in the primary resources demonstrates that the pools of nitrogen were abundant and participated in the fractions that promoted high $\delta^{15} \mathrm{~N}$ variability in the sampled organisms. The length of the fractionation that occurred in the cycle of this isotopic element depends on many factors, including the substrate (nitrogen source) / product (plant) ratio, temperature and the specific enzymes or microorganism mediators of the ammonification, nitrification and denitrification reactions (Mariotti et al., 1981).

Spatial variability in $\delta^{15} \mathrm{~N}$, related to aquatic macrophytes (Boon and Bunn, 1994), phytoplankton and periphyton (Lopes et al., 2006), has been little discussed in previous literature. Significant spatial variability of up to $10 \%$ was found for aquatic macrophytes (Ludwigia peploides and the genus Myriophyllum) in the Murray River floodplain (Boon and Bunn, 1994). In the present study, $\mathrm{C}_{4}$ macrophytes showed a variability of $8.4 \%$ o among the collection sites.

The ammonium ion $\left(\mathrm{NH}_{4}^{+}\right)$is energetically more attractive than the nitrate ion $\left(\mathrm{NO}_{3}^{-}\right)$, due to its absorption inside the cells not requiring enzymatic reduction reactions, but as it is very scarce in the layers where phytoplankton are found, the nitrate ends up being the nitrogenous form most frequently used by vegetation (Esteves, 1998). The presence of more $\delta^{15} \mathrm{~N}$-enriched values in $\mathrm{C}_{4}$ macrophytes and phytoplankton shows that these vegetation use the nitrate more effectively in the Pau Véio Lake. The periphyton also assimilated the nitrate in Fechada Lake, in addition to being influenced by associated heterotrophic organisms that raised their isotopic signal (because these organisms are rich in ${ }^{15} \mathrm{~N}$ ), as vegetation that assimilates the nitrate shows more $\delta^{15} \mathrm{~N}$-enriched values than those that use the ammonium ion (Pennock et al., 1996). The nitrate has greater mobility in the ecosystem and therefore suffers less exposure time to fractionating processes (Shearer and Kohl, 1988; Robinson, 2001). Furthermore, emergent macrophytes, such as $\mathrm{C}_{4}$ plants, collected in the study area, showed a greater capacity to store nitrogen (Henry-Silva and Camargo, 2000), with the sediment being their main food source (Camargo et al., 2003). Such a fact suggests that they exploit heavy-isotope and fractionated forms in such aquatic environments due positive values.

Nitrogen excreted by animals is typically depleted in $\delta^{15} \mathrm{~N}$ in relation to their diet (De Niro and Epstein, 1981; Checkley and Miller, 1989), promoting fractions that enrich the isotopic value of their tissues. Thus, $\delta^{15} \mathrm{~N}$ is consistently fractioned along the food chain and therefore permits inferences about the trophic position of organisms (Cabana and Rasmussen, 1994; Vander-Zanden et al., 1997). Trophic position based on $\delta^{15} \mathrm{~N}$, according to Post (2002), is considered to be a highly efficient tool that indicates the number of times that energy or material is transferred from the food chain to the organism investigated. In fish, the $\delta^{15} \mathrm{~N}$ fraction, per trophic level, is around 2.3\%o (adapted from McCutchan-Jr. et al., 2003), and those with isotopic values closer to plants are considered to be their direct consumers.

The role of the involvement of nitrogen biogeochemistry in the isotopic variability of the organisms in food chains is still not well understood (Pruell et al., 2006). The $\delta^{15} \mathrm{~N}$ variation in fish is often small, when they use the same source of food (Gu et al., 1997). However, the type of diet, form of excretion (McCutchan-Jr. et al., 2003), size of the organisms (Pinnegar and Polunin, 1999) and habitat (France and Steedman, 1996) are important factors that affect the determination of the length of the isotopic fractions, and consequently, the isotopic variability of the animals. High isotopic fractions also occur due to a lack or low availability of food (Scrimgeour et al., 1995). In these circumstances, the rate of $\mathrm{N}$ excretion is greater than that of assimilation, and its recycling becomes necessary to maintain the metabolism of the organism (Gannes et al., 1998). Furthermore, the greater availability of varied food raised the occurrence of high isotopic fractions by the animals (McCutchan-Jr. et al., 2003).

The fish analyzed in the present study showed high variability, around $11 \%$, reflecting the exploitation of a wide variety of food items and/or the presence of accentuated fractioning processes, independent of the fact that they exploit the same aquatic environment: the benthic zones of the areas studied. This variability was also high for other trophic categories (Fry and Sherr, 1984; Michener and Schell, 1994; Gu et al., 1996; 1997) and for detritivorous fish from the Paraguai River floodplain (Mato Grosso do Sul) (Calheiros, 2003). In the tropics, fish often show considerable feeding versatility (Abelha et al., 2001), due to the great variety of food resources available in the ecosystems (Goulding, 1997), which often makes the search for delineated trophic patterns (seasonal, intra and/or inter-local, and producer- and consumer-species) difficult.

The significant spatial variability in the isotopic composition of $P$. lineatus and $L$. platymetopon was characterized by the exploitation of more $\delta^{15} \mathrm{~N}$-enriched food sources in the Paraná River and Pau Véio Lake. Loricariichthys platymetopon also showed spatial variability related to trophic position, which was also greater in these two locations. Fine particulate detritus contains little refractory material (Bowen, 1984), together with a high protein content (Kondratieff and Simmons-Jr., 1984), which may explain the considerable presence of enriched $\delta^{15} \mathrm{~N}$ in the composition of fish that exploit this type of detritus, as is the case, according to Hahn et al. (1998), for iliophagous fish. However, the majority of fish belonging to other trophic categories and vegetation analyzed had enriched heavy-isotope values in the Paraná River and Pau Véio Lake. Thus, in these environments, other fish also assimilated, in an accentu- 
ated manner, protein-rich fine particulate detritus, such as that of animal origin, and/or selectively ingested zoobenthonic invertebrates and organisms participating in the microbial loop. These conditions could justify the higher trophic positions of $H$. littorale in the Baía River and Ventura Lake. Considering the fact that the changes in the trophic structure of these fish are highly dependent on interactions with the biotic and abiotic conditions of the environment, it can be seen that it is necessary to consider possible variability related to habitat in studies of energy flow in food chains.

Apareiodon affinis, L. platymetopon and $S$. pappaterra had the highest mean isotopic compositions and the highest trophic positions, and showed evidence of the consumption of more heavy-isotope and/or protein-enriched sources compared to the other species that composed these trophic categories. Prochilodus lineatus, despite occupying up to the third trophic level, was characterized by having the lowest compositions and trophic positions among the iliophagous fish, probably due to the ingestion of isotopically light food items with a lower participation of nitrogen from animal origin and high from plants.

For the Upper Paraná River floodplain, Hahn et al. (1998) reported a predominance of detritus and sediment and the presence of insects and other invertebrates in the stomachs of L. platymetopon, and classified it as detritivorous. A similar feeding tendency was recorded for S. pappaterra, although as well as invertebrates, this species had fish present in its diet, and it was considered to be benthophagous. When investigating the trophic structure of three lakes (Pousada, Figueira and Genipapo) on the Paraná River floodplain, Luz et al. (2001) described S. pappaterra as a detritivore consuming non-particulate detritus associated to organic vegetal material and the remains and excrement of invertebrates. In the Rosana Reservoir, located on the Paranapanema River, Casatti et al. (2003) characterized S. pappaterra as an algivorous species, which predominantly feeds on diatomaceous and chlorophyte algae and macrophyte periderm, together with sediment. An analysis of feeding and trophic ecomorphology carried out by Hahn and Cunha (2005) in the Manso Reservoir, Mato Grosso, resulted in the classification of $S$. pappaterra as a detritivore/invertivore. In the first three years of the study, during the formation of the reservoir, the species mainly exploited a large quantity of detritus (a mixture of the remains of plants and sand) and, later, proceeded to select benthonic organisms.

The presence of organic animal material in stomach-content analysis studies on L. platymetopon and $S$. pappaterra coincides with the high isotopic signatures of these species in the present study. Thus, the animalorigin nitrogen may be contributing to the isotopic enrichment of the fish.

For A. affinis, Hahn et al. (1998) reported an iliophagous feeding habit in the Itaipu Reservoir with a predominance of sediment and detritus composed of algae, showing the exploitation of basal food chain resources. Casatti et al. (2003) reported an algivorous feeding habit for this species in the Rosana Reservoir, Paranapanema River (São Paulo). However, the isotopic analyses of fish in the Upper Paraná River floodplain disagree with these findings, as this fish has occupied the fourth trophic level, indicating the assimilation of enriched sources of nitrogen, more typically related to the contribution of consumers.

Various researchers have suggested considering the participation of the microbial loop in the transfer of energy in order to understand the trophic relations in aquatic food chains (Lopes and Benedito-Cecilio, 2002; Manetta et al., 2003; Calheiros, 2003). Bacteria and other microorganisms that are exploited by the consumers can promote the incorporation of food sources that belong to diverse trophic levels. The participation of methanotrophic bacteria, which are extremely impoverished in nitrogen, along the detritivorous food chain can promote very low values in the consumers (Calheiros, 2003), countering the high isotopic enrichments with increases in trophic level. On the other hand, the incorporation of $\delta^{15} \mathrm{~N}$-enriched sources, through other microorganisms, is important for understanding the occupation of trophic positions above those of primary producers, characteristic of species that primarily exploit algae, as was the case especially for A. affinis, P. lineatus and other iliophagous species sampled in the Paraná River and Pau Véio Lake.

The significant differences both in isotopic composition and in trophic position among the species that made up each trophic category were contradictory to the classifications of Hahn et al. (1998). These isotopic differences may be seen by observing, for example, that the largest and the smallest mean isotopic compositions occurred among fish of the same category: the benthophagous group.

The information obtained in the present study regarding the trophic position structure of the bottom-feeding fish contributes to the realization that generalizations related to the grouping of fish into trophic and/or habitat categories in studies of energy flow in detrital food chains should be made only after detailed studies on the local/organism-specific trophic dynamics, using stable isotope analysis.

Considering that autotrophic organisms manufacture food from simple inorganic substances and make nutrients available for the consumers of food chains (Lopes and Benedito-Cecilio, 2002), and that the energy of the primary producers is assimilated directly or indirectly by bottom-feeding fish, it is clear that the management and conservation of the environmental health and, consequently, of these food sources is indispensable to the survival and maintenance of high biomass of these fish in tropical aquatic ecosystems.

Acknowledgements - The authors would like to thank the Post-Graduate Program in the Ecology of Continental Aquatic Environments (PEA - UEM) and CNPq for financial support, the PELD (UEM - NUPELIA) fieldwork teams for help in 
the collection of biological material, the Zoology (DBI), Zooplankton, Phytoplankton, Periphyton, Riparian Forest and Limnology (NUPELIA) laboratories for logistic support, Maria Salete Ribellato Arita and João Fábio Hildebrant for help with bibliographical material, and the biologists Kazue Kawakita Kita, MSc., Anna Christina Faria, MSc. and Dr. Gislaine Iachstel Manetta for their suggestions. The manuscript was translated by Peter Grimshaw.

\section{References}

ABELHA, MCF., AGOSTINHO, AA. and GOULART, E., 2001. Plasticidade trófica em peixes de água doce. Acta Scientiarum. Biological Sciences, vol. 23, no. 2, p. 425-434.

BOON, PI. and BUNN, SE., 1994. Variations in the stable isotope composition of aquatic plants and their implications for food web analysis. Aquatic Botany, vol. 48, no. 2, p. 99-108.

BOWEN, SH., 1983. Detritivory in neotropical fish communities. Environmental Biology of Fishes, vol. 9, no. 2, p. 137-144.

1984. Evidence of a detritus food chain based on consumption of organic precipitates. Bulletin of Marine Science, vol. 35 , no. 3 , p. $440-448$.

BUCKUP, PA., MENEZES, NA. and GHAZZI, MS., 2007. Catálogo das espécies de peixes de água doce do Brasil. Rio de Janeiro: Museu Nacional. 195p.

CABANA, G. and RASMUSSEN, JB., 1994. Modelling food chain structure and contaminant bioaccumulation using stable nitrogen isotopes. Nature, vol. 372, no. 17, p. 255-257.

CALHEIROS, DF., 2003. Influência do pulso de inundação na composição isotópica $\left(\delta^{13} \mathrm{C}\right.$ e $\left.\delta^{15} \mathrm{~N}\right)$ das fontes primárias de energia na planície de inundação do rio Paraguai (Pantanal - MS). São Paulo: Universidade de São Paulo. 186p. Tese de Doutorado.

CAMARGO, AFM., PEZZATO, MM. and HENRY-SILVA, GG., 2003. Fatores limitantes à produção primária de macrófitas aquáticas. In THOMAZ, SM. and BINI, LM. (Eds.). Ecologia e manejo de macrófitas aquáticas. Maringá: EDUEM. p. 59-83.

CAMPOS, JB. and SOUZA, MC., 1997. Vegetação. In VAZZOLER, AEAM., AGOSTINHO, AA. and HAHN, NS. (Eds.). A planície de inundação do alto rio Paraná: aspectos físicos, biológicos e socioeconômicos. Maringá: EDUEM. p. 331-342.

CASATTI, L., MENDES, HF. and FERREIRA, KM., 2003. Aquatic macrophytes as feeding site for small fishes in the Rosana Reservoir, Paranapanema River, southeastern Brazil. Revista Brasileira de Biologia = Brazilian Journal of Biology, vol. 63 , no. 2, p. 213-222.

CHECKLEY, DMJ. and MILLER, CA., 1989. Nitrogen isotope fractionation by oceanic zooplankton. Deep-Sea Research, vol. 36 , no. 10 , p. 1449-1456.

De NIRO, ML. and EPSTEIN, S., 1981. Influence of diet on the distribution of nitrogen isotopes in animals. Geochimica et Cosmochimica Acta, vol. 45, no. 3, p. 341-351.

ESTEVES, FA., 1998. Fundamentos de limnologia. Rio de Janeiro: Interciência. 602p.

FLECKER, AS., 1996. Ecosystem engineering by a dominant detritivore in a diverse tropical stream. Ecology, vol. 77, no. 6, p. $1845-1854$.
FRANCE, R. and STEEDMAN, R., 1996. Energy provenance for juvenile lake trout in small Canadian Shield Lakes as shown by stable isotopes. Transactions of the American Fisheries Society, vol. 125, no. 3, p. 512-518.

FRY, B. and SHERR, EB., 1984. $\delta^{13} \mathrm{C}$ measurements as indicators of carbon flow in marine and freshwater ecosystems. Contributions in Marine Science, vol. 27, p. 13-47.

Fundação Universidade Estadual de Maringá - FUEM; SubPrograma de Meio Ambiente - CIAMB and Programa de Apoio ao Desenvolvimento Científico e Tecnológico - PADCT, 1993. Estudos ambientais na planície de inundação do rio Paraná no trecho compreendido entre a foz do rio Paranapanema e o reservatório de Itaipu. Maringá: Fundação da Universidade Estadual de Maringá; NUPELIA. Relatório. Vol. 3.

FUGI, R., 1993. Estratégias alimentares utilizadas por cinco espécies de peixes comedoras de fundo do alto rio Paraná/PR$M S$. São Carlos: Universidade Federal de São Carlos. 142p. Dissertação de Mestrado.

FUGI, R., HAHN, NS. and AGOSTINHO, AA., 1996. Feeding styles of five species of bottom-feeding fishes of the high Paraná river. Environmental Biology of Fishes, vol. 46, no. 3, p. 297-307.

GANNES, LZ., RIO, CM. and KOCH, P., 1998. Natural abundance variations in stable isotopes and their potential uses in animal physiological ecology. Comparative Biochemistry Physiology, vol. 119, no. 3, p. 725-737.

GNERI, FS. and ANGELESCU, V., 1951. La nutricion de los peces iliofagos. Revista del Instituto Nacional de Investigaciones de las Ciencias Naturales, vol. 2, no. 1, p. 1-44.

GOTELLI, NJ. and ENTSMINGER, GL., 2003. EcoSim: null models software for ecology. Available from: <http:// homepages.together.net/ gentsmin/ecosim.htm>. Access in: Agosto de 2006

GOULDING, M., 1997. História natural dos rios amazônicos. Brasília: Sociedade Civil Mamirauá; CNPq; Rainforest Alliance. 208p. Tradução de ACA. Santos and ML. Carvalho.

GU, B., SCHELSKE, CL. and HOYER, MV., 1996. Stable isotopes of carbon and nitrogen as indicators of diet and trophic structure of the fish community in a shallow hypertrophic lake. Journal Fish Biology, vol. 49, no. 6, p. 1233-1243.

1997. Intrapopulation feeding diversity in blue tilapia: evidence from stable isotope analyses. Ecology, vol. 78, no. 7, p. 2263-2266.

HAHN, NS., ANDRIAN, IF., FUGI, R. and ALMEIDA, VLL., 1997. Ecologia trófica. In VAZOLLER, AEAAM., AGOSTINHO, AA. and HAHN, NS. (Eds.). A planície de inundação do rio Paraná: aspectos físicos, biológicos e socioeconômicos. Maringá: EDUEM; NUPELIA. p. 209-228.

HAHN, NS., AGOSTINHO, AA., GOMES, LC. and BINI, LM., 1998. Estrutura trófica da ictiofauna do reservatório de Itaipu (Paraná, Brasil) nos primeiros anos de sua formação. Interciência, vol. 23, no. 5, p. 299-305.

HAHN, NS. and CUNHA, F., 2005. Feeding and trophic ecomorphology of Satanoperca pappaterra (Pisces, Cichlidae) in the Manso reservoir, Mato Grosso state, Brazil. Brazilian Archives Biology Technology, vol. 48, no. 6, p. 1007-1012.

HAMILTON, SK. and LEWIS Jr., WM., 1992. Stable carbon and nitrogen isotopes in algae and detritus from the Orinoco 
river floodplain, Venezuela. Geochimica et Cosmochimica Acta, vol. 56 , no. 12 , p. 4237-4246.

HENRY-SILVA, GG. and CAMARGO, AFM., 2000. Composição química de quatro espécies de macrófitas aquáticas e possibilidade de uso de suas biomassas. Naturalia, vol. 25, p. 111-125.

JÚLIO Jr., HF., PETRY, AC., RUSSO, MR. and GOMES, LC., 2000. Ictiofauna. Maringá: Universidade Estadual de Maringá; Núcleo de Pesquisas em Limnologia, Ictiologia e Aqüicultura. p. 31-147. Relatório técnico 2000. Available from: <http//www. peld.uem.br/Relatorio/index.htm>. Access in: Setembro de 2006.

KONDRATIEFF, PF. and SIMMONS Jr., GM., 1984. Nutritive quality and size fractions of natural seston in an impounded river. Archiv fur Hydrobioogie, vol. 101, no. 3, p. 401-402.

LOLIS, AA. and ANDRIAN, IF., 1996. Alimentação de Pimelodus maculatus Lacépède, 1803 (Siluriformes, Pimelodidae), na planície de inundação do alto rio Paraná. Boletim do Instituto de Pesca, vol. 23, p. 187-202.

LOPES, CA. and BENEDITO-CECILIO, E., 2002. Variabilidade isotópica $\left(\delta^{13} \mathrm{C}\right.$ e $\left.\delta^{15} \mathrm{~N}\right)$ em produtores primários terrestres e de água doce. Acta Scientiarum. Biological Sciences, vol. 24, no. 2, p. 303-312.

LOPES, CA., BENEDITO-CECILIO, E., MARTINELLI, LA. and SOUZA, MC., 2006. Variability of $\delta^{13} \mathrm{C}$ and $\delta^{15} \mathrm{~N}$ in terrestrial and aquatic sources in the upper Paraná river basin, Paraná, Brazil. Acta Limnologica Brasiliensia, vol. 18, no. 3, p. 281-292.

LOPES, CA., BENEDITO-CECILIO, E. and MARTINELLI, LA., 2007. Variability in the carbon isotope signature of Prochilodus lineatus (Prochilodontidae, Characiformes) a bottom-feeding fish of the Neotropical region. Journal of Fish Biology, vol. 70, no. 6, p. 1649-1659.

LOWE-MCCONNELL, RH., 1987. Ecological studies in tropical fish communities. Cambridge: University Press. 382p.

LUZ, KDG., ABUJANRA, F., AGOSTINHO, AA. and GOMES, LC., 2001. Caracterização trófica da ictiofauna de três lagoas da planície aluvial do alto rio Paraná, Brasil. Acta Scientiarum. Biological Sciences, vol. 23, no. 2, p. 401-407.

MANETTA, GI., BENEDITO-CECILIO, E. and MARTINELLI, LA., 2003. Carbon sources and trophic position of the main species of fihes of Baía river, Paraná river floodplain, Brazil. Revista Brasileira de Biologia = Brazilian Journal Biology, vol. 63 , no. 2, p. 283-290.

MARIOTTI, A., GERMON, JC. and HUBERT, P., 1981. Experimental determination of nitrogen kinetic isotope fractionations: some principles; ilustration for he denitrification and nitrification processes. Plant Soil, vol. 62, no. 3, p. $413-430$.
McCUTCHAN Jr., JH., LEWIS, Jr., WM., KENDALL, C. and McGRATH, CC., 2003. Variation in trophic shift for stable isotope ratios of carbon, nitrogen, and sulfur. Oikos, vol. 102, no. 2, p. 378-390.

MICHENER, RH. and SCHELL, DM., 1994. Stable isotope ratios as tracers in marine aquatic food webs. In LAJTHA, K. and MICHENER, RH. (Eds.). Stable isotopes in ecology and environmental science. Oxford: Blackwell Scientific Publications. p. 138-157.

PENNOCK, JR., VELINSKY, DJ., LUDLAM, JM., SHARP, JH. and FOGEL, ML., 1996. Isotopic fractionation of ammonium and nitrate during uptake by Skeletonema costatum: implications for $\delta^{15} \mathrm{~N}$ dynamics under bloom conditions. Limnology and Oceanogrophy, vol. 41, no. 3, p. 1195-1213.

PINNEGAR, JK. and POLUNIN, NVC., 1999. Differential fractionation of $\delta^{13} \mathrm{C}$ and $\delta^{15} \mathrm{~N}$ among fish tissues: implications for the study of trophic interactions. Functional Ecology, vol. 13 , no. 2, p. 225-231.

POST, DM., 2002. Using stable isotopes to estimate trophic position: models, methods and assumptions. Ecology, vol. 83, no. 3, p. 703-718.

PRUELL, R., TAPLIN, BK., LAKE, JL. and JAYARAMAN, S., 2006. Nitrogen isotope ratios in estuarine biota collected along a nutrient gradient in Narragansett Bay, Rhode Island, USA. Marine Pollution Bulletin, vol. 52, no. 6, p. 612-620.

ROBINSON, D., 2001. $\delta^{15} \mathrm{~N}$ as an integrator of the nitrogen cycle. Trends in Ecology \& Evolution, vol. 16, no. 3, p. 153-162.

SCRIMGEOUR, CM., GORDON, SC., HANDLEY, LL. and WOODFORD, JAT., 1995. Trophic levels and anomalous $\delta^{15} \mathrm{~N}$ of insects on raspberry (Rubus idaeus L.). Isotopes Environmental Health Studies, vol. 31, no. 1, p. 107-115.

SHEARER, G. and KOHL, DH., 1988. Estimates of $\mathrm{N}_{2}$ fixation in ecosystems: the need for and basis of the ${ }^{15} \mathrm{~N}$ natural abundance method. In RUNDEL, JR., EHLERINGER, JR. and NAGY, KA. (Eds.). Stable isotopes in ecological research. New York: Springer-Verlag. p. 342-374.

VANDER-ZANDEN, MI. and RASMUSSEN, JB., 1996. A trophic position model of pelagic food webs: impact on contaminant biomagnification in lake trout. Ecological Monographs, vol. 66, no. 4, p. 451-477.

VANDER-ZANDEN, MJ., CABANA, G. and RASMUSSEM, JB., 1997. Comparing trophic position of freshwater fish calculated using stable nitrogen isotope ratios $\left(\delta^{15} \mathrm{~N}\right)$ and literature dietary data. Canadian Journal Fisheries Aquatic Sciences, vol. 54, no. 5, p. 1142-1158.

YI, X., YANG, Y. and ZHANG, X., 2006. Modeling trophic positions of the alpine meadow ecosystem combining stable carbon and nitrogen isotope ratios. Ecological Modelling, vol. 193 , no. $3-4$, p. $801-808$. 